\title{
DIREITA PARA O SOCIAL, ESQUERDA PARA O CAPITAL*
}

\author{
SILVANA APARECIDA DE SouZA**
}

$\mathrm{L}$

ançado em outubro de 2010, na 32ª Reunião Anual da Associação Nacional de Pós-Graduação e Pesquisa em Educação (ANPEd), pela editora Xamã, com cuidadoso prefácio de Roberto Leher e apresentação de Eurelino Coelho, Direita para o social e esquerda para o capital: intelectuais da nova pedagogia da hegemonia no Brasil é organizado por Lúcia Maria Wanderley Neves, professora aposentada da Universidade Federal de Pernambuco (UfPe), pesquisadora da Escola Politécnica de Saúde Joaquim Venâncio, Fundação Oswaldo Cruz (EPSJv-Fiocruz) e coordenadora do Coletivo de Estudos de Política Educacional ligado àquela instituição. Com larga experiência e apoiada no referencial teórico marxista/gramsciano - a partir do qual tem desenvolvido um continuum de estudos e pesquisas em políticas e educação no Brasil, em suas relações com o processo permanente de reestruturação do modo de produção capitalista -, Lúcia Neves é autora, coautora e organizadora de diversos outros livros na área educacional.

Os demais autores do livro - André Silva Martins, Daniela Motta de Oliveira, Ialê Falleiros, Marcela Alejandra Pronko, Marcelo Paula de Melo, Marco Antonio Carvalho Santos, Maria Teresa Cavalcanti de Oliveira e Vanja da Rocha Monteiro - integram o Coletivo de Estudos de Política Educacional coordenado por Lúcia Neves.

Tendo como recorte as relações superestruturais que produzem e reproduzem a alienação na sociedade capitalista, o título do livro per si já é bastante provocador e, por isso, um convite instigante à leitura.

Escrito de forma coletiva, seus autores, em uma demonstração de domínio do pensamento do italiano Antonio Gramsci, tratam do processo de formação e de

Resenha do livro Direita para o social e esquerda para o capital: intelectuais da nova pedagogia da hegemonia no Brasil, organizado por Lúcia Maria Wanderley Neves (São Paulo: Xamã, 2010).

* Doutora em Educação e professora da Universidade Estadual do Oeste do Paraná (UNIOESTE). E-mail: souzasilvana@uol.com.br 
atuação instrumental dos intelectuais orgânicos ou tradicionais, individuais ou cole$\operatorname{tivos}^{1}$ na sociedade, sobretudo no momento histórico atual.

Para além do alto domínio conceitual e teórico, os autores demonstram, do ponto de vista histórico, a constituição e os determinantes do processo de propagação das ideias que fundamentam "a nova pedagogia da hegemonia", mais especificamente na sociedade capitalista contemporânea. Tratam do contexto da Guerra Fria, apontando um conjunto de ações desenvolvidas na época de ouro do capitalismo para efetivar uma verdadeira campanha cultural, cujo objetivo era difundir na intelectualidade ocidental não só a aceitação como a exaltação do "americanismo" como modo de vida. O objetivo de tal campanha era fazer com que o poder de formação de opinião das massas que a intelectualidade detém se voltasse a favor do American way of life.

A partir daí, os autores listam uma série de instituições de natureza pública e/ou privada, criadas na América Latina e no Brasil, com o objetivo de orientar as políticas públicas, a tomada de decisão dos governos e constituir um quadro de servidores públicos de carreira formados a partir de uma concepção desenvolvimentista, mas, antes de tudo, anticomunista. ${ }^{2}$

Na década de 1970 teve início um processo de crise no interior do capitalismo que levou ao fortalecimento da doutrina neoliberal e que propiciou, em pouco tempo, a "mundialização do capital, com seus exorbitantes ganhos financeiros e suas desastrosas consequências no aprofundamento das desigualdades sociais" (Neves, 2010, p. 66).

Data desse período a origem da Terceira Via, que se apresentou como alternativa indispensável para "suprimir o potencial de conflito dos primeiros regimes de direita radical (Thatcher e Reagan), eliminando a oposição ainda existente à hegemonia neoliberal" (idem, ibid., p. 70), quando passou a ocorrer a formação de uma nova subjetividade coletiva que resultou em uma nova sociabilidade, que tem se traduzido em uma prática política da direita para o social e da esquerda para o capital.

Nesse contexto, o grupo, que é profícuo em cunhar expressões - condição que acaba por caracterizar sua forma bem humorada de produzir explicações que retratem sofisticadamente o real -, utilizando-se metaforicamente de um fenômeno da natureza, chama de "pororoca do novo mundo" o encontro de correntes políticas distintas, à direita para o social e à esquerda para o capital, que atualmente se traduz na chamada Terceira Via.

A partir de então, os autores se propõem a explicitar os fundamentos teóricos que dão sustentação ao projeto neoliberal da Terceira Via no Brasil e, para tanto, realizam a análise dos princípios da "pedagogia da hegemonia". Para esta tarefa, selecionaram obras clássicas de vários teóricos, de diferentes áreas, que sustentam, 
com alguma diferença entre eles, que a atual fase do capitalismo se configura como um mundo novo. Isso está de acordo com a teoria do fim das classes e de que o trabalho não é mais categoria central para explicação da realidade e sim o conhecimento, a linguagem, a informação ou a cultura. Os teóricos analisados são: Alain Touraine, Adam Schaff, Robert Putnam, Peter Drucker, Boaventura de Souza Santos, Manuel Castells, Edgar Morin, Zygmunt Bauman, Michel Hardt e Antonio Negri.

Na última parte do livro os autores se ocupam da análise da influência dos "intelectuais coletivos" com atuação na formação política e escolar da sociedade brasileira contemporânea, tendo escolhido para o estudo de caso a Fundação Getúlio Vargas (FGV) e o Instituto Brasileiro de Análises Sociais e Econômicas (IBASE), ambos pelo papel formador dos quadros intelectuais brasileiros, tanto para a área pública quanto para a privada.

No que diz respeito à FGV, que, desde sua criação em 1944, forma gestores para o setor público e para o campo empresarial privado, sua influência é extensa na definição de políticas públicas no país, pois muitos de seus professores e pesquisadores ocuparam e ocupam cargos importantes no governo federal; a Fundação, por intermédio de seus vários institutos, tem prestado permanentemente consultoria e assessoria econômica a governos brasileiros; possui vasta e diversificada linha editorial de revistas científicas, entre as mais conceituadas do país na área de Administração e Economia; organiza e realiza uma diversidade enorme de eventos, congressos e seminários nacionais e internacionais; nos últimos anos, cresceu sobremaneira sua atuação na prestação de serviços de consultoria para o setor privado, assim como na oferta de serviços educacionais (cursos de curta duração, de graduação e pós-graduação, nas modalidades presencial e a distância), formando gestores agora também para a chamada economia social, solidária ou ligada ao Terceiro Setor.

Já o IBASE foi inicialmente administrado por exilados e políticos cassados pela ditadura militar, que retornaram ao país com a anistia política de 1979, e tinha por principal objetivo prestar assessoria aos movimentos sociais comprometidos com a democratização do Brasil. No entanto, com o passar do tempo, seus objetivos foram mudando e hoje o Instituto atua, sobretudo, junto às organizações não governamentais (ONG) voltadas à prestação de serviços sociais para segmentos populacionais considerados "excluídos".

Assim, a pesquisa demonstra que tanto a FGV quanto o IBASE, na condição de organizações da sociedade civil, atuam, cada uma a seu modo, como intelectuais coletivos na legitimação da nova pedagogia da hegemonia, de acordo com os preceitos da Terceira Via.

É com esta análise da influência dos intelectuais coletivos que os autores optam por terminar o livro sem tecer as conhecidas "considerações finais", ou mesmo 
uma síntese, presente no encerramento da maioria de estudos dessa natureza. Porém, considerando que Direita para o social... constitui uma sequência articulada às discussões realizadas em trabalho anterior ( $A$ nova pedagogia da hegemonia), arriscaria dizer que a forma como o livro termina sugere que teremos uma espécie de trilogia, pois é sabido que o Coletivo de Estudos de Política Educacional continua cada vez mais bem articulado e está com nova pesquisa em andamento, que, norteada pelo mesmo referencial teórico, agora contempla a análise do chão da realidade escolar pública brasileira.

Enfim, o livro coordenado por Lúcia Neves se apresenta como uma referência importante para o debate da esquerda educacional brasileira, por sua relevância teórica, pela pertinência das relações que estabelece, mas, sobretudo, por não perder a perspectiva da ruptura com a lógica destrutiva do capital.

\section{Notas}

1. Antonio Gramsci entendia por intelectuais indivíduos ou organizações formadoras, organizadoras e/ou propagadoras, em diferentes linguagens, da cultura e das ideias que fundamentam uma determinada concepção de mundo e de classe. Portanto, em acordo com a conceituação gramsciana, um partido, um sindicato, a Igreja ou qualquer outra organização podem assumir, em qualquer momento, a condição de intelectual coletivo.

2. Observe-se que, de acordo com a teoria gramsciana, a sociedade civil pode dar certa direção às políticas públicas, por meio de organizações que se convertem em intelectuais coletivos, o que, em sua teoria de Estado, denomina-se "aparelhos privados de hegemonia". No entanto o autor esclarece que a classe dominante tem melhores condições de fazer isso do que a classe que luta no plano contra-hegemônico (Gramsci, 2000).

\section{Referências}

GRAMSCI, A. Cadernos do cárcere. v. 3. Rio de Janeiro: Civilização Brasileira, 2000.

NEVES, L.M.W. (Org.). A nova pedagogia da hegemonia: estratégias do capital para educar o consenso. São Paulo: Xamã, 2005.

NEVES, L.M.W. (Org.). Direita para o social e esquerda para o capital: intelectuais da nova pedagogia da hegemonia no Brasil. São Paulo: Xamã, 2010. 